\title{
Knowledge, Attitude and Practice towards Anthrax in Northern Ethiopia: a mixed approach study
}

\section{Gebremedhin Romha ( $\nabla$ gebremdhin.romha@mu.edu.et )}

Mekelle University College of Veterinary Medicine https://orcid.org/0000-0002-3115-8121

\section{Weldemelak Girmay}

Mekelle University College of Veterinary Medicine

\section{Research Article}

Keywords: Anthrax, knowledge-Attitude-practice, Ethiopia, Tigray

Posted Date: May 29th, 2020

DOI: https://doi.org/10.21203/rs.3.rs-31528/v1

License: (c) (7) This work is licensed under a Creative Commons Attribution 4.0 International License. Read Full License

Version of Record: A version of this preprint was published at BMC Infectious Diseases on November 10th, 2020. See the published version at https://doi.org/10.1186/s12879-020-05544-z. 


\section{Abstract}

Background Anthrax is prioritized as the second diseases in Ethiopia based on its negative impacts at the household level by causing disease or production losses in livestock and sever disease in human. This study aimed at assessing the knowledge, attitude and practices (KAPs) of anthrax in the communities of Eastern Tigray, Northern Ethiopia. Methods A cross-sectional survey was concurrently conducted with focus group discussions (FGD) and key informant interviews (KII) from May 2019 to April 2020. A total of 862 respondents have participated in the questionnaire survey. Of which, 800 were local community members. While 62 were professionals working at animal and human health service institutions. Likewise, qualitative data were collected using six FGDs and $11 \mathrm{KIlls}$. Results sixty two percent $(496 / 800)$ of the respondents said that they knew the disease anthrax while $38 \%(304 / 800)$ of them did not it. Only $9.3 \%(74 / 800)$ of the respondents reported germ as the causative agent of anthrax. About $56.5 \%(35 / 62)$ of the professional respondents said that the causative agent of the disease was bacteria while 33.9\% (21/62) of them did not know it. More than sixty percent $(64.1 \%, 513 / 800)$ did not know whether the disease was zoonotic or not. Among the listed clinical signs, $26.3 \%(210 / 800)$ and $36.8 \%$ (294/800) of the respondent knew at least one signs in animal and human, respectively while $21.3 \%(170 / 800)$ and $20.1 \%(161 / 800)$ knew one or more transmission routes in animal and human respectively. Moreover, $43.4 \%$ (347/800) and 45.6\% (365/800) of the respondents mentioned one or more control/prevention method in animal and human, respectively. Fifty two (416/800) and $32.4 \%(259 / 800)$ of the questionnaire participants believed that vaccination of animals could prevent anthrax in animal and human, respectively. But although 4\% (32/800) said that they had anthrax (Megerem ) infected animals, more than $28 \%$ (9/32) of them used traditional medication for their animals. Regarding qualitative results, some of the participants knew the disease (in animals) in their own local names, Lalish and Tafia (splenomegaly), and Gulbus (abdominal cramp and shivering). Some had perceived the disease only as human disease while others recognized after they were told its clinical signs in animals and humans. Conclusion The KAP of the participants towards anthrax was low. Moreover, there was no similar understanding of the disease among the participants. The study also revealed that the participants did not get consistent, adequate and continuous health messages regarding the disease. Traditional belief and socio-economic factors impacted the KAP of the community towards the disease.

\section{Background}

Anthrax is a neglected tropical zoonotic disease of economic and public health importance [1]. It is estimated that 20,000-100,000 incidence of human anthrax occur per year globally [2] with significant number of cases from Chad, Ethiopia, Zambia, Zimbabwe and India [1]. However, the true disease burden is likely unknown as there are poor surveillance systems and unreliable reporting [3]. The causative agent of anthrax is, Bacillus anthracis (B. anthracis), which primarily infects herbivores and secondarily afflicts humans $[4,5]$. The most common source of infection for ruminants is ingestion of spores during grazing in contaminated pastures, or through grass and water contaminated with anthrax spores [6-8]. Animals also become infected through concentrated feed include bone meal [9].

The occurrence of anthrax outbreaks in a particular location mostly depends on the existence of interacting factors, which include unique characteristics of the bacterium, environmentally related features, animal densities and human activities $[10,11]$. It was also found that outbreak of anthrax had been associated with ecological, demographic, and sociocultural factors $[12,13]$. Seasonal variation of livestock and human anthrax has been reported because occurrence of human cases was highly correlated with animal anthrax outbreaks [14]. Anthrax epidemics are frequent in the dry season and are generally associated with onset of the first rains $[15,16]$. During the dry season, the grass is short and animals are, thereby, forced to graze very close to the ground, and animals have chances of picking up anthrax spores [17] as anthrax-infected carcasses and butchering waste have disposed in environments where ruminants live and graze [18]. Spores may be spread in the environment through scavenging birds, animals, and water 
$[6,19]$. Repeated anthrax outbreaks in animals without vaccination have reported [18] since ongoing vaccination programs can break the cycle of transmission in domestic animals $[7,18]$.

Human infection is often, associated with eating meat of ill animals $[20,21]$ and, a result of coming into contact with infected animals or contaminated animal materials during agricultural activities including the butchering of livestock or industrial exposures through the processing of hair and bone [5, 20-24]. One of the drivers that may contribute to the persistence of anthrax is human behavior [25]. For instance, in Kenya, it was reported that human anthrax cases most often occur linked to animal anthrax. In most cases, human behaviors, especially slaughter and consumption of meat from animal anthrax cases, has been implicated [26]. In Zambia, Popular cultural practices that involved exchange of animals between herds contributed to uncontrolled cattle movements between herds facilitate subsequent transmission of anthrax [13]. In Tanzania, it has been documented that demographic characteristics, sleeping on animal's skins, contacting with infected carcasses through skinning and butchering, and not having formal education were linked to exposure for anthrax infection [20]. Because animals are an important asset to the communities affected, death of an animal may result in consumption of infected meat and use of animal products, potentially leading to infections. In Bangladesh, it was identified that skinners removed and sold the hides from discarded carcasses even though Islamic law forbids eating animals that die from natural causes [18]. This is worsened by the fact that a family may consume and sell some of the meat in order to salvage some losses from the death of the animal $[17,18,25,27]$.

According to Pieracci et al. [28], the United States center of disease control (US-CDC) and other concerned Ethiopian and North American organizations, have prioritized five zoonotic diseases in Ethiopia based on 1) severity of disease in humans, 2) proportion of human disease attributed to animal exposure, 3) burden of animal disease, 4) availability of interventions, and 5) existing inter-sectoral collaboration. Accordingly, anthrax ranked second based on its negative impacts at the household level by causing disease or production losses in livestock and sever disease in human in the country. In Ethiopia, government reports indicated that a total of 5197 and 26737 cases and 86 and 8523 deaths of human and animal anthrax respectively were documented from 2009 to 2013 [29]. Nonetheless, deficiencies in diagnostic testing services and the non-specific presentation of many zoonoses can lead to failure to confirm diagnosis as well as a failure to reinforce awareness of cases [30]. So also, another study reported that lack of awareness on zoonotic diseases was due to poor communication between veterinarian and human health-care professionals and lack of involvement of educated family members in farming activities [31]. Specifically, in Zambia it had been reported that the persistence of anthrax outbreak was linked to perceptions, beliefs and practices of farmers, which meant that cattle farmers were reluctant to have their livestock vaccinated against anthrax because of perceived low efficacy of the vaccine, and besides, farmers did not trust professional staff and their technical interventions [13].

Establishing a bond of trust between responsible authorities and those who are potentially affected communities through effective communication would create sensitive control strategy [32]. This might contribute to improved compliance to control measures and application of empirical evidence based on both technical and locally acceptable interventions [27]. It has been acknowledged that cultural issues are always an important component of health, especially in agrarian communities [33]. Human behavior [25] and socio-demographic factors [20] could affect the KAP of a given communities towards anthrax. Having evidence of KAP regarding anthrax can be used to set the prevention strategy against the disease. Hence, this study aimed at assessing the knowledge, attitude and practice of anthrax at Adigrat town, Ganta Afeshum and Gulomkada districts.

\section{Methods}

\section{Description of study area}


Eastern zone is among the seven zonal administrative units of Tigray regional state which consists of 9 districts. Of which two are town districts while the remaining 7 are rural districts. Adigrat is the capital town of the zone. The zone is located at $14^{0} 16^{\prime} \mathrm{N} 39^{0} 27^{\prime} \mathrm{E}$ longitude and $14^{0} 16^{\prime} \mathrm{N} 39^{0} 27^{\prime} \mathrm{E}$ latitude; with an altitude ranges from 2000-3000 meter above sea level. The average annual rainfall is $552 \mathrm{~mm}$ and that of temperature is $16^{\circ} \mathrm{C}$. The study was conducted in three districts of Eastern zone, namely, Adigrat town, Ganta Afeshum and Gulomkada (Fig 1).

\section{Definitions}

1. Zone is a large political administrative unit next to regional state.

2. Ketena and Kushet (urban and rural, respectively) are the smallest administrative units in the study region, Tigray - both are synonymous with parish.

3. Tabia is an administrative units larger than Ketena and Kushet but smaller than districts.

4. Community member: in this paper, community member used only to differentiate respondents who are not professional/experts, FGD participants and key informants.

\section{Study design}

The study used a mixed-method design employing both quantitative and qualitative methods. A cross-sectional survey was concurrently conducted with FGD and KII from May 2019 to April 2020.

\section{Sample selection and healthcare sector description}

The study districts were selected purposively. In total, 10 tabias were included in the study. Three from each district, were randomly selected: Adigrat (01, 03 and 05 tabias), Gan-afeshum (Bizet, Bahrasehita and Hagereselam) and Gulomkada (Fatsi, Kokobtsibah, Anbesetefikada). One tabia (Sebeya) from Gulomkada which had anthrax outbreak in 2018 was purposively included. All parishes under the selected tabias were included. Inclusion criteria were logistic feasibility and history of anthrax outbreak. Initial survey was conducted to collect the number of households and populations from each selected tabia and parish. Besides, animal and human healthcare sectors were identified. In animal healthcare sector, there were three clinics, one for each district. They provided veterinary service based on clinical signs with few broad spectrum medicaments. Rural tabias had no permanent veterinary facilities. They were reached from the respective district center/clinic for vaccination and sometimes for case management. Healthcare coverage is better in human than animal sector. Formal clinical services were provided through health posts, clinics/health centers and hospitals. Our rural study tabias had one health center each except Bahrasehita and Anbesetefikada which got healthcare from the neighbor tabias. Adigrat town had one general hospital and two health centers. Lists of households were not available. Hence, Respondent households were selected using systematic random sampling while all health professionals available at the time of visiting were included.

\section{Data collection}

\section{Quantitative}

Structured-questionnaire with mostly close-ended questions was prepared. It was translated into local language, Tigrigna, and translation was done back into English to keep the consistency. Enumerators, with University degree whose mother tongue and currently spoke Tigrigna, were selected. Training for enumerators was given. In addition to the content of the questionnaire, enumerators were tutored about the disease by using some supportive pictures which showed some clinical signs including cutaneous lesion in human and bleeding from natural orifices from dead animals. The authors themselves participated in data collection. Data collection format was prepared for individual 
case. The questionnaire was tested in both rural and urban residents. In this study, a total of 862 respondents were interviewed. Of which, 800 were urban and rural dwellers. While 62 were professionals/experts working at animal and human health service institutions: 49 human health practitioners (HHPs) and 13 animal health experts (AHEs). For the community, one person per household with age of $\geq 18$ years old was interviewed - Interview was held face to face by the enumerators. While health workers were given the questionnaire and allowed to answer the questions by themselves.

The questionnaires were of two types: one for the community members (Additional file: Questionnaire A) and another one for professionals (Additional file: Questionnaire B) with slice differences for animal and human professionals. The first questionnaire comprised: socio-demographic information of the respondent (age, sex, educational status, occupation, religion), animal ownership, questions related to knowledge (e.g. knowledge on the disease, source/cause of the disease, signs of the disease in animal and human, transmission routes to animal and human, prevention methods in animal and human), attitude (e.g. seriousness of the disease in animals and humans and the importance of vaccination) and practice related questions (e.g. animal vaccination and frequency and medication of animal and humans). The second questionnaire aimed at assessing the knowledge of the disease amongst health professionals. Majority of the questionnaires' components were the same with the first one. However, some additional questions were incorporated: questions related to knowledge (e.g. etiology of the disease, form of anthrax, transmission route form each form), questions related to outbreak and case admission to animal and human healthcare centers (e.g. occurrence of outbreak in animal and human, number of cases admitted in animal and human healthcare center, number of recovery and death in animal and human).

\section{Qualitative}

Six FGD and $11 \mathrm{KII}$ were conducted. The FGD participants were individuals who did not take part in the questionnaire survey. Each group was composed of both sexes, farmers and local leaders. The FGDs meetings were modulated by both the researchers and each discussion was held until it reached saturation point, an average of $\approx 40$ minutes. The mean age of the FGDs participants was 44 (range: 24-78). The FGDs were consisting of 7-15 (total of 58) participants. Focus group discussions were held in six tabias: three from Gulomkada (Fatsi, Anbesetefikada and Sebeya), one from Adigrat town and two from Ganta-afeshum (Hagereselam and Bizet). The FGDs were always begun with the animal health coordinators highlighted the purpose of the discussion. The participants were encouraged to speak their opinions. And they were left for sometimes to made side talk (help each other) in order to explore the question/matter being asked/raised until brought back their attention (handing their idea) to the stage by the researchers.

Eleven KII were held with concerned officers responsible for anthrax control/prevention: Amongst the 11 officers interviewed, 7 were human health officers (HHOs) and 4 were animal health officers (AHOs): five from Gulomkada (human health officers, $n=3$; animal health officers, $n=2$ ), Ganta-afeshum, (human health officers, $n=2$; animal health officers, $n=1$ ) and Adigrat (human health officers, $n=2$; animal health officers, $n=1)$. One (1/11) of them was female while the remaining interviewees $(10 / 11)$ were males.

Interview with key informants and focus group discussions were held with the local language, Tigrigna. Both the FGDs and the KII were conducted using interview guides with open ended questions/themes (Additional file: Questionnaire C) to allow the participants to express freely their views and thoughts in their own words on the subject matter, and were recorded on a digital recorder after getting verbal consent from the participants. During interview, the interviewer was taking responsibility, not to leave the themes.

\section{Data management and statistical analysis}


Quantitative data were run using STATA statistical software (version 14.0, Stata Corp, college station, Texas 77845 USA) for analysis. To ensure quality, data were crosschecked independently by the researchers. The effects of sociodemographic factors (such as age, sex, educational level, district, occupation, religion and animal ownership) on knowledge of the disease, and its causative agent, zoonotic nature, symptoms, transmission and control/prevention methods were analyzed using descriptive statistics. Moreover, with 95\% confidence intervals, logistic regression model was used to evaluate the association between the outcome (e.g., knowledge on the disease its zoonotic nature) and the aforementioned socio-demographic variables. A P-value $<0.05$ was considered statistically significant.

Qualitative data collected through audio recorder first were transcribed into computer files and then were translated from the local language Tigrigna into English. Thematic analysis was used as described in Graneheim and Lundman [34]. The narratives were read several times to understand the whole sense of the text. After setting the major themes, texts were extracted and brought under each theme. Illustrative quotations that clearly represented the themes were used in the results.

\section{Results}

\section{Quantitative}

\section{Socio-demographic characteristics}

Of the 800 rural and urban residents, $54.9 \%(439 / 800)$ and $45.1 \%(361 / 800)$ were males and females, respectively. Mean age of the respondents was 46.7 (95\% Cl: 45.6-47.9) with a range of $18-90$ years. About 38.8\% (310/800), $31.6 \%$ (253/800) and 29.6\% (237/800) were from Gulomkada, Gant-afeshum and Adigrat districts, respectively. Regarding the professionals, 49.2\% (30/61) were males while 50.8\% (31/61) were females. More than sixty percent $(61.7 \%, 37 / 62)$ were diploma graduated while 33.3\% (20/62) and 5\% (3/62) were respectively first and second degree holders. About $85.5 \%(53 / 62)$ had been working in urban settings and remaining $(14.5 \%, 9 / 62)$ was in rural areas (Table 1).

\section{Knowledge on the disease, its causative agent and zoonotic nature}

Community members: sixty two percent (496/800) of the respondents said that they knew the disease anthrax, locally (in Tigrigna) called Megerem. However, 38\% (304/800) of them said that they did not know the disease. The proportion who knew anthrax was greater in female $(63.4 \%, 229 / 361)$ than in male $(60.8 \%, 267 / 439)$ respondents. Greater number $(77.6 \%, 621 / 800)$ of the respondents reported that they did not know the cause of the disease (Table 2). However, of the respondents $(22.4 \%, 179 / 800)$ who believed to have known the cause of the disease: Only $9.3 \%$ $(74 / 800)$ said that the disease was caused by germ. About $8.9 \%(71 / 800)$ believed that the disease was God given, and $4.3 \%$ (34/800) mentioned other entities (heredity, witchcraft, lack of sanitation, hunger, insects and thirst) as causative agent of the disease. Of the respondents who claimed knowing the disease, majority $(63.9 \%, 317 / 496)$ of them responded as they did not know the causative agent of the disease (Table 2). Regarding the zoonotic importance of the disease, more than sixty percent $(64.1,513 / 800)$ did not know whether the disease was zoonotic or not. About $20.1 \%$ (161/800) of respondents claimed that anthrax had zoonotic nature while $15.8 \%(126 / 800)$ said that the disease was not zoonotic (Table 2). Knowledge of respondents on anthrax increased with age. As age of respondent increases, knowledge on anthrax increases (Additional file: Fig A). Socio-demographic factors in relation to knowledge of anthrax, and its causative agent and zoonotic nature were presented in Table 2.

Logistic regression model was used to determine the effect of socio-demographic factors (age, sex, district, level of education, occupation and animal ownership) on knowledge and zoonotic nature of anthrax. Accordingly, age, sex, 
district, occupation and animal ownership had statistical significant association with knowledge of the disease anthrax. Age group of 58-65 were found 7 times knowledgeable about the disease (OR: 6.7; 95\% $\mathrm{Cl}$ : 2.80-16.01; $\mathrm{p}<0.001)$ than age group of $18-25$ years old. Male (OR: $0.6 ; 95 \% \mathrm{Cl}: 0.40-0.85 ; \mathrm{p}<0.005)$ and merchants $(\mathrm{OR}: 0.3 ; 95 \%$ Cl: $0.12-0.80 ; p=0.016)$ respondents, and participants from Gulomkada (OR: 0.3; $95 \% \mathrm{Cl}: 0.19-0.53 ; p<0.001)$ had significantly lower level of knowledge on anthrax than female, civil servants and participants from Adigrat, respectively. Respondents who owned animals (OR: 1.8; 95\% $\mathrm{Cl}$ : 1.10-2.83; $\mathrm{p}=0.02$ ) had better knowledge on anthrax than respondents who did not have animals. However, only district had statistical significant association with awareness of zoonotic nature of the disease. Respondents from Ganta-afeshum (OR: 0.4; $95 \%$ Cl: 0.19-0.65; $p<0.001$ ) had low level of awareness on the zoonotic nature of the disease than respondents from Adigrat.

Professionals: About $56.6 \%$ of the respondents said that the causative agent of the disease was bacteria while $33.9 \%$ of them did not know it. However, $9.7 \%$ claimed that the causative agent of anthrax was other organisms (Leishmania and fly). Cutaneous form (67.2\%) was the most known form of the disease. More than ninety percent (90.1\%) of the professional respondents knew that anthrax was zoonotic (Table 3). Socio-demographic factors such as age, sex, Profession (animal and human experts) and level of education were analysed using logistic regression model whether there was statistical association with the knowledge of the causative agent and zoonotic nature of anthrax or not. None of them found statistically significant.

The respondents of the community members learned about anthrax: $55.8 \%$ (446/800) from family, friends and neighbours/colleagues, $2.8 \%$ (22/800) from health experts, $2.1 \%$ (17/800) from radio and $2 \%(16 / 800)$ from veterinary experts (Additional file: Table A and Fig B).

\section{Knowledge on symptoms, transmission, and control/prevention methods in animals}

Community members: The number of community member respondents who knew one or more symptoms, transmission and control/prevention methods of anthrax in animals was 26.3 (210/800), 21.3 (170/800) and 43.4\% (347/800), respectively. Respondents who did not know symptoms, transmission and control/prevention methods of anthrax were 73.8 (590/800), 78.8 (630/800) and 56.6\% (453/800), respectively. The most known symptom, transmission route and prevention methods by the communities were sudden death in cattle (14.4\%), ingesting of blood contaminated grass (13\%) and isolation of anthrax infected animals (7.6\%), respectively (Table 4).

Professionals: The number of professional respondents who reported for each one or more symptoms, transmission and control/prevention methods of animal anthrax was 74.2 (46/62), 79 (49/62) and 80.7\% (50/62), respectively. Sudden death (53.2\%) and contaminated soil (56.5\%) were the most common symptom and transmission route, respectively, while they reported that vaccination (67.7\%) of animals were the most effective control/prevention methods (Table 4).

\section{Knowledge on symptoms, transmission, and control/prevention methods in humans}

Community members: The number of respondents who knew at least one anthrax symptom in humans was $36.8 \%$ $(294 / 800)$ which was greater than in animals $(26.3 \%, 210 / 800)$, and the most recognized symptom by the respondents was fever (22.4\%). Moreover, respondents who mentioned one or more transmission routes and control/prevention methods of human anthrax were 20.1 (161/800) and 45.6\% (365/800), respectively. The respondent considered that consumption of infected animal products (raw meat \& milk) was the common transmission route (15.9\%) while vaccination of animals (34.5\%) was effective mechanisms of control/prevention methods (Table 6).

Professionals: More than ninety percent of the professional respondents knew for each one or more anthrax symptoms, transmission routes and prevention methods. The most recognized symptom, transmission route and 
control and prevention methods were skin rash (cutaneous wound) $(66.1 \%, 41 / 62)$, consumption of infected animal products (raw meat and milk) $(83.9 \%, 52 / 62)$ and vaccination of animals $(67.7 \%, 42 / 62)$, respectively (Table 6).

\section{Attitude and practice towards anthrax}

Fifty two (416/800) and $32.4 \%$ (259/800) of the questionnaire participants believed that vaccination of animals could prevent anthrax in animal and human, respectively. But although $4 \%(32 / 800)$ said that they had anthrax (Megerem) infected animals, more than $28 \%$ (9/32) of them used traditional medication for their animals. Moreover, of the $10.5 \%$ (84/800) respondents who had anthrax infected family member, 71.4\% (60/84) visited local healers (Table 6).

\section{Qualitative}

\section{Knowledge on anthrax/Megerem}

Different local name of the disease in animals in different locality: The researchers approached the participants by using the local name Megerem which is commonly known in Tigray. However, the researchers gave opportunities to the participants to name their own local name of the disease by telling the clinical signs of the disease in animals and humans when they failed to recognize the name Megerem. Because farmers usually named diseases based on their clinical signs and lesion/pathology they found in animals.

... I do not know the disease Megerem, but I have heard about it. But I know Lalish and Gulbus in animals (male participant, Sebeya). This participant called another person for help, a deacon male participant. The second participant had given similar opinion with some clarifications.

...I do not know Megerem in animals. Perhaps we can learn from you. But in cattle, there are other diseases I know. One is "Lalish", enlargement of the spleen. Moreover, there is another fatal disease called "Gulbus" showing cramp like symptoms and shivering. This disease may sometimes be confined around the head (neck swelling), in this case animal may not die soon (the deacon male participant, Sebeya). This idea was supported by most of this FGD (Sebeya) participants. The FGDs participants from Ganta-afeshum district had similar understanding about the disease. A 78 age male participant named the disease in animals Tafia (enlargement of spleen) (Hagereselam tabia, Ganta-afeshum district). Similar suggestions had been given in Bizet tabia of the same district. Especially, a female participant told that Lalish was a sever disease of cattle (Bizet tabia, Ganta-afeshum district).

Anthrax/Megerem perceived only as human disease: The deacon participant from Sebeya said that Megerem appears in the neck/face of humans and could not be cured without treatment (modern medication). Another female participant from the same area shared her knowledge about human Megerem. ... My daughter (one year old) was sick (swelling in the wrist). My daughter was waiting without medication for few days. When the swelling has become bigger and bigger, I took my daughter to health center. After medication, she cured but she was suffered.

The researcher asked: What look likes the swelling? The same female participant responded: the swelling starts with small size. Then it increases in size with depressed black eschar in the center.

The researcher added another question: Do you think that this disease can attack animals? I do not know. Where your daughter acquired the disease from? ... I did not know its origin or from where it came. If I had known that I could have prevented and/or taken quick measure for my daughter during her suffering.

Indeed, the second female participant from the same group partially supported the idea of the first female participant but she had different view in the characteristics of the disease. This participant did not agree with the first female participant, especially with the nature of the lesion (depressed black eschar) in the center of the swelling. She said that 
the swelling had no depressed black eschar (Sebeya tabia, Gulomkada district). A female participant from Bizet tabia fanatically said that it should not be talking about Lalish in front of animals because animals could be panic when they heard the word Lalish - indeed; she reflected the belief of the community. However, she failed to relate with human Megerem (Bizet tabia, Ganta-afeshum district).

Anthrax perceived by the participants after they had been told its clinical signs: Most FGD participants from Fatsi and Anbesetefikada tabias (both from Gulomkada district) told that they did not know the disease Megerem/anthrax, and the disease has not occurred in their locality. However, after the researchers had explained the nature/signs of the disease in animals and humans, few individuals tried to share what they have heard/known about the disease.

... I have seen bleeding from natural orifices of dead animals. But I do not know the name of the disease (male participant, Fatsi). Other participants said that they have seen bleeding through natural orifices and absence of rigor mortis of dead animals but they did not relate to Megerem (Hagereselam and Bizet, Ganta-afeshum district).

\section{Knowledge on the causative agent, transmission and control/prevention methods on anthrax/Megerem}

Most FGDs participants did not know the causative agent, transmission and control/prevention methods of anthrax/Megerem in animals and humans. Some of the participants associated Megerem in animals with the local belief, Weqh'e (unidentified cause but they told that it caused sudden death): but the participants believed that it can be transmitted to humans through consumption of meat. Some of the participants also believed that the disease could occur in humans when there was stress (e.g. thirst, starvation), and consumption of meat and alcohol might exacerbate the disease. According to these participants, the disease was commonly seen in poor body condition animals, and exacerbated when diseased animals had consumed water. Few participants mentioned that the disease was caused by germs. Regarding the control/prevention methods, FGDs participants agreed that though the disease had been treated using traditional medicine, nowadays modern medication has become their best option in animals and humans. However, some of the participants still believed in traditional medicine - heating, the spleen using hot iron or, around the bottom part of the neck if there was swelling and bloodletting in animals were commonly used. All the FGDs participants did not recognize the GIT and pulmonary forms of the disease in human.

\section{Attitude and practice}

Some of the participants knew the disease (in animals) in other names, Lalish and Tafia (splenomegaly) and Gulbus (abdominal cramp and shivering). Some had perceived the disease only as human disease while others recognized after they were told its clinical signs in animals and humans. Most of the participants failed to know the transmission routes of the disease among animals as well as its zoonotic importance. But during the discussion, they remembered that the general health education given by the experts, i.e. not to eat carcass of dead animals. Some of the participants said that they were told not to eat animals died from anthrax/Megerem.

... I have heard that if animals died of Megerem, they should have not been eaten their meat and touched their blood. But the community did not perform it (male participant, Fatsi). In Sebeya, the researchers raised the issues of the outbreak occurred in 2018, and asked the participants regarding the transmission routes and control/prevention measure to be taken: ... We had been informed that a girl (tenth grade student) has died of eating dead animal meat. And experts told us that animal died of such kind of disease should have not been eaten... (Participants from Sebeya).

According to the key informants, eating habit and living style of the communities would risky to contract anthrax. ... Indeed, there were no animals died from anthrax. But if animals died of any cases (for example rabies), individuals would resist burying the carcass; they need to consume it (Meida Agame health center director, Adigrat town district). Other key informants said that the communities had lived with their livestock in the same house (indeed poverty is our 
main challenge) (Tekhli Siwuat health center director (Adigrat), and they slaughtered animals for meat purpose at home (never use abattoir) (Bizet health center director, Ganta-afeshum district). Another challenge reported by officers is that the negative attitude of the community towards animal vaccination against infectious diseases (including anthrax) (Gulomkada district animal health and Adigrat Veterinary clinic coordinators). Instead, they prefer visiting the local healers to modern treatment and vaccination (Gulomkada District Health coordinator).

\section{Reasons of low KAP of the community towards anthrax}

In general, the low KAP towards anthrax was arisen from three different reasons:

\section{1) Animal and human health officers}

Anthrax as a forgotten disease: Key informants already admitted that their respective communities had low KAP towards anthrax and they said that the disease was not their priority to be prevented:

.... Our community has low awareness towards anthrax because we do not deliver adequate health education specific to anthrax. Since the disease is not common, it is not in our top lists. Rather we do inform the community the general impacts about zoonotic diseases like tuberculosis and rabies (Fatsi health center director). Likewise, the director of Tekli Siwuat health center of Adigrat said: ... we have no scheduled separate prevention program against anthrax. But we try to associate with rabies prevention program (according to the director, rabies outbreak was common in the town).

Similar suggestions have been given by other human health officers (Adi-aynom and Meida Agame health center officers from Ganta-afeshum and Adigrat town districts, respectively). They said that anthrax cases were not admitted to their health centers. Moreover, they told that the disease had not occurred in their surroundings and that is why health education given specifically against anthrax was poor. One of the key informant described anthrax as a "forgotten" disease. ... long time ago there were rare anthrax cases but nowadays it is being forgotten (Meida Agame health center director, Adigrat town district).

Irregular health education: Some of the key informants said that health educations were conducted in Sebeya and Bizet where anthrax outbreaks had occurred in their locality. The director of Sebeya health center said: ...there was an outbreak that killed a girl and left diseased others in a village called Adibeteksian (Adibeteksian found in Sebeya tabia). The source of the case was a cow died from anthrax. The girl was presented to our clinic with high abdominal cramp and fever. ... though finally the cause was role out as anthrax (by Aider specialized hospital), we failed to save the life of that innocent girl. The then time, we have begun health education together with the veterinarians in the area. We started teaching the community during the funeral of the girl that it was because of the delay that she lost her life so that they must immediately bring their children when they observe such signs, and should avoid consuming animals that are sick and even carcass of apparently healthy animals which are not properly inspected.

The animal science and health district (of Gulomkada) coordinators confirmed the above suggestions, i.e. after the outbreak of anthrax occurred in Sebeya (in 2018), awareness creation education towards anthrax has been started in Sebeya and its surroundings. However, from the interviews held, we found that though health educations were concentrated in areas where there were anthrax outbreaks, health educations could not continue when the outbreak has been controlled: ... During the anthrax outbreak (to control the disease) we were doing with the human health professionals in an integrated way. However, after controlling the disease we did not continue to work together for prevention purpose (Animal science district coordinator- Gulomkada).

\section{2) Government}


Since anthrax is a neglected tropical disease, the government of Ethiopia has not given priority for anthrax. Government has not been funding specifically for anthrax prevention program. Neither health education specific to anthrax nor human anthrax vaccine was given.

... So far, we do have more than 15 vaccines but there is no human anthrax vaccine independently or in combination with others (Fatsi health center director, Gulomkada district). Moreover, though anthrax can be prevented using anteand postmortem inspections, it was indicated that there was no proper abattoir and slaughtering method (Bizet health center director, Ganta-afeshum district). The officer added that there was no even a single investor that could invest on abattoir. Other officers reported that there was inadequate veterinary clinics and drugs in (Animal science district coordinator- Gulomkada), and man power (Adigrat Veterinary clinic coordinator) to tackle the disease. ... There were also remote areas where we cannot access it via vehicles even during the epidemics of anthrax. ...Nowadays the community is reluctant to the local delivering (by gathering people) way of health education; the community may need modern mass Medias staying at home which the government ought to have afforded (Gulomkada District Health coordinator).

\section{3) Community}

The negative attitude of the community towards anthrax contributed its own challenge to the prevention of anthrax. Focus group discussions and KIls revealed that the community has still stuck to local beliefs. Even though the communities were not given adequate educations, they also resist implementing what they have been told, and fix themselves to the traditional way of living style.

\section{Discussion}

Anthrax is a neglected tropical disease, and it is hardly studied in Ethiopia. Pieracci et al. [28] have prioritized that anthrax as the second disease in Ethiopia based on its negative impacts at the household level by causing disease or production losses in livestock and sever disease in human. However, this study showed that anthrax has not been given yet any priority in Ethiopia. Key informants from Gulomkada said that anthrax has been a problem in the community which caused human death and socio-economic crisis. But another key informant from Adigrat said that anthrax was a forgotten disease. This indicated that there was no anthrax control/prevention program coordinated by the central government. In our study, socio-demographic/social differences of the study community (age, sex, animal ownership, and district) were significantly associated with the knowledge of the disease.

Link and Phelan [35] indicated that social conditions (e.g. race, socioeconomic status, gender, and other stressful life events of a social nature) are going to be fundamental causes of diseases. Moreover, In West Africa, during the epidemic of Ebola, the traditions of local communities frequently challenged the control program of the disease [36]. These problems could be solved by education. The Health Belief Model posits that messages will achieve optimal behavioral change if they successfully target perceived barriers, benefits, self-efficacy, and threat [37].

Even though $62 \%$ of respondents said that they knew the disease anthrax/Megerem, only $9.3 \%$ of them explained its causative agent, i.e. the germ. About $9 \%$ and $4.3 \%$ believed that as if the disease were God given and caused by other entities (heredity, witchcraft, lack of sanitation, hunger, insects, thirst), respectively while $77.6 \%$ did not know the causative agent of the disease. Among the listed clinical signs, only $26.3 \%$ and $36.8 \%$ of the respondent name at least one signs in animal and human, respectively. During the questionnaire survey data collection, we observed that some respondent perceived staphylococcal skin infection, locally (in Tigrigna) called Migli Chiwa, as cutaneous anthrax in humans. We had also been encountered similar condition in animals. According the FGDs, in animals, the swelling was developed around the lower neck which was not fatal, locally called Zigag. This might be mistaken with the throat 
swelling caused by subacute form of anthrax [1]. The poor understanding of the study community on the overall of the disease was revealed by qualitative results. In fact, similar findings were reported from Zambia: quantitative results showed good awareness among respondents while qualitative results indicated poor knowledge of the same communities on the disease [27].

More than $38 \%$ of the respondents had no formal education. It was also reported by the key informants that except in Sebeya (education was given during the outbreak), health education was not given. Hence, it was not expected that the study community could have been aware regarding the disease. This scenario is similar with Sitali et al. [27] who suggested that education influences one's access to information and ability to comprehend health messages. Even involvement of educated family members in farming practices can create awareness and improve knowledge toward zoonotic disease [31]. Indeed, the present study community did not find adequate public health messages. Among the survey respondents who claimed to have known anthrax (496/800), about $90 \%(446 / 496)$ of them acquired information regarding the disease from family, friends and neighbours/colleagues, which might expose the community members to seek misconceptions and myths surrounding the disease [27].

During the FGDs, some participants said that they did not know Megerem in animals but Lalish and Tafia (splenomegaly) and Gulbus (abdominal cramp and shivering), and others described the clinical signs like bleeding in dead animals. These circumstances indicated the absence/lack of consistent health education in the study area. Consistent with this study, Opare et al. [25] showed that most respondents did not know the causes of anthrax but recognized the signs of the disease. Moreover, in the questionnaire survey, the number of respondents who knew the clinical signs was better than respondents who knew the cause of the disease. Although 74.2 and $90.3 \%$ of the professional respondents name at least one sign of the disease, only $55.7 \%$ of them knew the causative agent of the disease.

About 10 and $11 \%$ of the respondents had felt that anthrax was a serious disease of animals and humans, respectively. And 52 and $32.4 \%$ of them believed that vaccination could prevent the disease in animals and humans. However, only $4.4 \%$ (35/800) of them have vaccinated their animals. In general, we observed the KAP of the respondents on anthrax: knowledge was better than attitude, and attitude was better than practice. This is supported by a study conducted in Ghana which indicated that high levels of knowledge of the farmers on vaccination had not been realized into practices [25].

In fact, practice might be influenced by culture and socio-economic factors. The deep-rooted belief could not be changed unless the Health Belief model variables successfully inculcated in the community. This model suggested that individuals who perceive a risk which can cause low health problem are unlikely to engage in behaviors to reduce their risk of developing that particular health problem; hence, optimal behavioral change is achieved if the Health Belief Model successfully target perceived barriers, benefits, self-efficacy, and threat [37].

Participants from Sebeya tabia said that they had been informed that the meat of an infected animal was the cause for the death of the girl. But the participant uncovered his reluctance to the public health messages given. In the Ebola period of West Africa, some of the local people not only detached themselves off from help but also they were fighting the prevention program delegations and killed eight members. Finally, control and prevention program was successful when the community was made part of the program using social mobilization action [36]. Other reports indicated that how notions of 'the community' can be problematic if used uncritically [38, 39].

On the other hand, socio-economic factors could affect a practice made to avoid a given risk. One of the key informants pointed out "indeed poverty is our main challenge". This was to claim that the community had lived with their livestock in the same house. According to other key informants, the community resisted to bury the carcass of

Page 12/23 
dead animals. Consumption and selling of animal carcass died from anthrax was reported by other studies: this is not only to make financial return but also as a source of protein [14, 25, 27,40]. Key informants also said that there were remote and inaccessible areas which could not get veterinary services. Sitali et al. $[13,27]$ reported that practices that can be used to prevent anthrax have been impacted by infrastructure. Bruce and Phelan (1995) postulated the essential feature of fundamental social causes which involve access to resources (e.g. money, knowledge, power, prestige) that can be used to avoid risks or to minimize the consequences of disease once it occurs. Likewise, similar theory was formulated by Phelan et al. [41] which states differences in socio-economic status brings inequality in health.

The study has its own limitations. There was no common local name for anthrax in the study areas. During our quick survey, we identified that anthrax was commonly called Megerem. This local name is widely known in Tgray. But some of our study village residents called the disease with different local names. During interview, the respondents could not understand the disease, their response might be "No or I did not know", or they understood the disease differently (mostly Megli Chiwa in human and Zigag in animals - both are non-fatal swellings). Having felt this problem, we trained our enumerators how to approach the respondents who had different understanding about the disease. The presence of local veterinarian during the discussion might also bias the response of the FGDs participants.

\section{Conclusion}

In general, the KAP of the participants towards anthrax was low. Moreover, there was no similar understanding of the disease among the participants. The study also revealed that the participants did not get consistent, adequate and continuous health messages regarding the disease. Traditional belief and socio-economic factors impacted the KAP of the community towards the disease. During the epidemic of Ebola in West Africa, the communities of the respective countries not only resisted the health messages but also challenged the control program [36]. Hence, to hold health risky tradition by the community is not uncommon. It is the responsibility of the government and the experts to uproot this tradition. This can effectively be done through community-centered programs.

\section{Declarations}

\section{Acknowledgments}

The authors are indebted to individuals who consented to participate in this study.

\section{Funding}

The study was financially supported by Adigrat University (project ID number ADU/CAES/016/11).

\section{Availability of data and materials}

Data will not be made public to keep the confidentiality of the participants but can be obtained from authors on reasonable request. 
GR and WG designed the study and developed the questionnaire, collected the qualitative data, supervise and participated in the questionnaire survey data collection; GR analyzed and interpreted the data; GR and WG have drafted, critically reviewed and approved the manuscript.

\section{Ethics approval and consent to participate}

Ethical approval was obtained from Adigrat University, Deans and directors Committee (DDC) which was responsible for Research and Ethical issues. Moreover, oral informed consent was obtained from all interviewees.

\section{Consent for publication}

Not applicable.

\section{Competing interests}

The authors declare that they have no competing interests.

\section{Authors' information}

1 Department of Veterinary Public Health and Food Safety, College of Veterinary Sciences, Mekelle University, Ethiopia.

\section{References}

1. WHO: Anthrax in humans and animals. In., 4 edn; 2008.

2. Dutta T, Sujatha S, Sahoo R: Anthrax-update on diagnosis and management. J Assoc Physicians India 2011, 59:573-578.

3. Hendricks KA, Wright ME, Shadomy SV, Bradley JS, Morrow MG, Pavia AT, Rubinstein E, Holty J-EC, Messonnier NE, Smith TL: Centers for disease control and prevention expert panel meetings on prevention and treatment of anthrax in adults. Emerging infectious diseases 2014, 20(2).

4. Hugh-Jones M, Blackburn J: The ecology of Bacillus anthracis. Molecular aspects of medicine 2009, 30(6):356367.

5. Joyner TA, Lukhnova L, Pazilov Y, Temiralyeva G, Hugh-Jones ME, Aikimbayev A, Blackburn JK: Modeling the potential distribution of Bacillus anthracis under multiple climate change scenarios for Kazakhstan. PloS one 2010, 5(3).

6. Dragon DC, Rennie RP: The ecology of anthrax spores: tough but not invincible. The Canadian Veterinary Journal 1995, 36(5):295.

7. Mongoh MN, Dyer NW, Stoltenow CL, Khaitsa ML: Risk factors associated with anthrax outbreak in animals in North Dakota, 2005: A retrospective case-control study. Public Health Reports 2008, 123(3):352-359.

8. Ndiva Mongoh M, Dyer N, Stoltenow C, Hearne R, Khaitsa M: A review of management practices for the control of anthrax in animals: the 2005 anthrax epizootic in North Dakota-case study. Zoonoses and public health 2008, 
55(6):279-290.

9. Davies D, Harvey R: Anthrax infection in bone meal from various countries of origin. Epidemiology \& Infection 1972, 70(3):455-457.

10. Blackburn JK, Curtis A, Hadfield TL, O'Shea B, Mitchell MA, Hugh-Jones ME: Confirmation of Bacillus anthracis from flesh-eating flies collected during a West Texas anthrax season. Journal of wildlife diseases 2010, 46(3):918922.

11. Hugh-Jones M, De Vos V: Anthrax and wildlife. Revue Scientifique et Technique-Office International des Epizooties 2002, 21(1):359-384.

12. Muturi M, Gachohi J, Mwatondo A, Lekolool I, Gakuya F, Bett A, Osoro E, Bitek A, Thumbi SM, Munyua P: Recurrent anthrax outbreaks in humans, livestock, and wildlife in the same locality, Kenya, 2014-2017. The American Journal of Tropical Medicine and Hygiene 2018, 99(4):833-839.

13. Sitali DC, Twambo MC, Chisoni M, Bwalya MJ, Munyeme M: Lay perceptions, beliefs and practices linked to the persistence of anthrax outbreaks in cattle in the Western Province of Zambia. Onderstepoort Journal of Veterinary Research 2018, 85(1):1-8.

14. Munang'andu HM, Banda F, Siamudaala VM, Munyeme M, Kasanga CJ, Hamududu B: The effect of seasonal variation on anthrax epidemiology in the upper Zambezi floodplain of western Zambia. Journal of veterinary science 2012, 13(3):293-298.

15. Ministry of Agriculture FaF, MAFF Farmers' attitudes towards the control and prevention of anthrax in Western Province Zambia. Working paper,95/11. 1995.

16. Ministry of Agriculture FaF, MAFF: Report on a consultancy mission to assess the anthrax situation inWestern Province, Zambia. 1997.

17. Siamudaala VM, Bwalya JM, Munang'andu HM, Sinyangwe PG, Banda F, Mweene AS, Takada A, Kida H: Ecology and epidemiology of anthrax in cattle and humans in Zambia. Japanese Journal of Veterinary Research 2006, 54(1):15-23.

18. Islam MS, Hossain MJ, Mikolon A, Parveen S, Khan MSU, Haider N, Chakraborty A, Titu AMN, Rahman MW, Sazzad HM: Risk practices for animal and human anthrax in Bangladesh: an exploratory study. Infection ecology \& epidemiology 2013, 3(1):21356.

19. Fasanella A, Scasciamacchia S, Garofolo G, Giangaspero A, Tarsitano E, Adone R: Evaluation of the house fly Musca domestica as a mechanical vector for an anthrax. Plos one 2010, 5(8).

20. Mwakapeje ER, Høgset S, Softic A, Mghamba J, Nonga HE, Mdegela RH, Skjerve E: Risk factors for human cutaneous anthrax outbreaks in the hotspot districts of northern Tanzania: an unmatched case-control study. Royal Society open science 2018, 5(9):180479.

21. Nayak P, Sodha SV, Laserson KF, Padhi AK, Swain BK, Hossain SS, Shrivastava A, Khasnobis P, Venkatesh SR, Patnaik B: A cutaneous Anthrax outbreak in Koraput District of Odisha-India 2015. BMC public health 2019, 19(3):470.

22. Blackburn JK, McNyset KM, Curtis A, Hugh-Jones ME: Modeling the geographic distribution of Bacillus anthracis, the causative agent of anthrax disease, for the contiguous United States using predictive ecologic niche modeling. The American journal of tropical medicine and hygiene 2007, 77(6):1103-1110.

23. Mullins J, Lukhnova L, Aikimbayev A, Pazilov Y, Van Ert M, Blackburn JK: Ecological Niche Modelling of the Bacillus anthracis A1. a sub-lineage in Kazakhstan. BMC ecology 2011, 11(1):32.

24. Mwakapeje ER, Høgset S, Fyumagwa R, Nonga HE, Mdegela RH, Skjerve E: Anthrax outbreaks in the humanslivestock and wildlife interface areas of Northern Tanzania: a retrospective record review 2006-2016. BMC Public 
Health 2018, 18(1):106.

25. Opare C, Nsiire A, Awumbilla B, Akanmori B: Human behavioural factors implicated in outbreaks of human anthrax in the Tamale municipality of northern Ghana. Acta tropica 2000, 76(1):49-52.

26. Obonyo MO, Farr M, Hikufe EH, Rubanzana W, Owiny MO, Roka ZG: Investigation of anthrax in an endemic region in Kenya: a mixed methods approach. The Pan African Medical Journal 2018, 30(Suppl 1).

27. Sitali DC, Mumba C, Skjerve E, Mweemba O, Kabonesa C, Mwinyi MO, Nyakarahuka L, Muma JB: Awareness and attitudes towards anthrax and meat consumption practices among affected communities in Zambia: A mixed methods approach. PLoS neglected tropical diseases 2017, 11(5):e0005580.

28. Pieracci EG, Hall AJ, Gharpure R, Haile A, Walelign E, Deressa A, Bahiru G, Kibebe M, Walke H, Belay E: Prioritizing zoonotic diseases in Ethiopia using a one health approach. One Health 2016, 2:131-135.

29. Bahiru G, Bekele A, Seraw B, Boulanger L, Ali A: Human and animal anthrax in Ethiopia: A retrospective record review 2009-2013. Ethiopian Veterinary Journal 2016, 20(2):76-85.

30. Zhang HL, Mnzava KW, Mitchell ST, Melubo ML, Kibona TJ, Cleaveland S, Kazwala RR, Crump JA, Sharp JP, Halliday JE: Mixed methods survey of zoonotic disease awareness and practice among animal and human healthcare providers in Moshi, Tanzania. PLoS neglected tropical diseases 2016, 10(3).

31. Rajkumar K, Bhattacharya A, David S, Balaji SH, Hariharan R, Jayakumar M, Balaji N: Socio-demographic study on extent of knowledge, awareness, attitude, and risks of zoonotic diseases among livestock owners in Puducherry region. Veterinary world 2016, 9(9):1018.

32. Blanchard JC, Haywood Y, Stein BD, Tanielian TL, Stoto M, Lurie N: In their own words: lessons learned from those exposed to anthrax. American Journal of Public Health 2005, 95(3):489-495.

33. Dingwall R: Ebola-WHO (Still) don't get it: Social science saves lives'. Social Science Space 2015.

34. Graneheim UH, Lundman B: Qualitative content analysis in nursing research: concepts, procedures and measures to achieve trustworthiness. Nurse education today 2004, 24(2):105-112.

35. Link BG, Phelan J: Social conditions as fundamental causes of disease. Journal of health and social behavior 1995:80-94.

36. Wilkinson A, Parker M, Martineau F, Leach M: Engaging 'communities': anthropological insights from the West African Ebola epidemic. Philosophical Transactions of the Royal Society B: Biological Sciences 2017, 372(1721):20160305.

37. Jones CL, Jensen JD, Scherr CL, Brown NR, Christy K, Weaver J: The health belief model as an explanatory framework in communication research: Exploring parallel, serial, and moderated mediation. Health communication 2015, 30(6):566-576.

38. Espino F, Koops V, Manderson L: Community participation and tropical disease control in resource-poor settings. In.: World Health Organization; 2004.

39. Parker M, Polman K, Allen T: Neglected tropical diseases in biosocial perspective. Journal of biosocial science 2016, 48(S1):S1-S15.

40. Gombe N, Nkomo B, Chadambuka A, Shambira G, Tshimanga M: Risk factors for contracting anthrax in Kuwirirana ward, Gokwe North, Zimbabwe. African health sciences 2010, 10(2):159-164.

41. Phelan JC, Link BG, Tehranifar P: Social conditions as fundamental causes of health inequalities: theory, evidence, and policy implications. Journal of health and social behavior 2010, 51(1_suppl):S28-S40.

\section{Tables}


Table 1: Socio-demographic characteristics of the respondents

\begin{tabular}{|c|c|c|c|c|c|}
\hline \multirow{2}{*}{\multicolumn{2}{|c|}{ Variable }} & \multicolumn{2}{|c|}{ Professionals $(n=62)$} & \multicolumn{2}{|c|}{ Community $(n=800)$} \\
\hline & & Number & $\%$ & Number & $\%$ \\
\hline \multirow[t]{2}{*}{ Sex } & Female & 31 & 50.8 & 361 & 45.1 \\
\hline & Male & 30 & 49.1 & 439 & 54.9 \\
\hline \multirow[t]{7}{*}{ Age } & $18-25$ & 10 & 23.3 & 68 & 8.6 \\
\hline & $26-33$ & 22 & 51.2 & 124 & 15.7 \\
\hline & $34-41$ & 5 & 11.6 & 146 & 18.4 \\
\hline & $42-49$ & 3 & 7.0 & 116 & 14.7 \\
\hline & $50-57$ & 3 & 7.0 & 115 & 14.5 \\
\hline & $58-65$ & 0 & 0 & 101 & 12.8 \\
\hline & $>65$ & 0 & 0 & 122 & 15.4 \\
\hline \multirow[t]{8}{*}{ Education } & No formal education & - & - & 309 & 38.6 \\
\hline & $1-4$ & - & - & 110 & 13.8 \\
\hline & $5-8$ & - & - & 160 & 20 \\
\hline & $9-10$ & - & - & 136 & 17 \\
\hline & $11-12$ & - & - & 38 & 4.8 \\
\hline & Diploma & 37 & 61.7 & 27 & 3.4 \\
\hline & Degree & 20 & 33.3 & 18 & 2.3 \\
\hline & MSc & 3 & 5 & 2 & 0.3 \\
\hline \multirow[t]{7}{*}{ Occupation } & Civil servant & - & & 39 & 4.9 \\
\hline & Merchant & - & & 145 & 18.1 \\
\hline & Farmer & - & & 449 & 56.1 \\
\hline & Daily worker & - & & 44 & 5.5 \\
\hline & Students & - & & 18 & 1.6 \\
\hline & Other & - & & 12 & 1.5 \\
\hline & Unemployed & - & & 98 & 12.3 \\
\hline \multirow[t]{2}{*}{ Animal ownership } & Have & 13 & 21 & 452 & 56.5 \\
\hline & Have not & 49 & 79 & 348 & 43.5 \\
\hline \multirow[t]{3}{*}{ District } & Adigrat & 25 & 40.3 & 237 & 29.6 \\
\hline & Gulomkada & 17 & 27.4 & 310 & 38.8 \\
\hline & Ganta-afeshum & 20 & 32.3 & 253 & 31.6 \\
\hline \multirow[t]{4}{*}{ Religion } & Orthodox & 54 & 94.7 & 770 & 96.7 \\
\hline & Catholic & 2 & 3.5 & 6 & 0.8 \\
\hline & Muslim & 1 & 1.8 & 19 & 2.4 \\
\hline & Protestant & - & - & 1 & 0.1 \\
\hline \multirow[t]{2}{*}{ Profession } & Human health & 49 & 79 & - & - \\
\hline & Veterinarian & 13 & 21 & - & - \\
\hline
\end{tabular}

Table 2: Knowledge on the disease, its cause and zoonotic nature by the community member respondents 


\begin{tabular}{|c|c|c|c|c|c|c|c|c|c|c|}
\hline \multicolumn{2}{|c|}{ Variable } & \multicolumn{2}{|c|}{$\begin{array}{l}\text { Knowledge on the } \\
\text { disease }\end{array}$} & \multicolumn{4}{|c|}{ Knowledge on the cause of the disease } & \multicolumn{3}{|c|}{ Zoonotic nature } \\
\hline & & $\begin{array}{l}\text { Yes } \\
(\mathrm{n} / \%)\end{array}$ & $\begin{array}{c}\text { No } \\
(\mathrm{n} / \%)\end{array}$ & $\begin{array}{l}\text { Germ } \\
(\mathrm{n} / \%)\end{array}$ & $\begin{array}{l}\text { God } \\
\text { given } \\
(\mathrm{n} / \%) \\
\end{array}$ & $\begin{array}{l}{ }^{*} \text { Other } \\
(\mathrm{n} / \%\end{array}$ & $\begin{array}{l}\text { Don't } \\
\text { know } \\
(\mathrm{n} / \%)\end{array}$ & $\begin{array}{l}\text { Yes } \\
(\mathrm{n} / \%)\end{array}$ & $\begin{array}{l}\text { No } \\
\text { (n/\%) }\end{array}$ & $\begin{array}{l}\text { Don't } \\
\text { know } \\
(\mathrm{n} / \%) \\
\end{array}$ \\
\hline \multirow{3}{*}{$\begin{array}{l}\text { Sex } \quad(n= \\
800)\end{array}$} & Female & $229 / 63.4$ & $132 / 36.6$ & $22 / 6.1$ & $37 / 10.3$ & $14 / 3.9$ & $288 / 79.8$ & $66 / 18.3$ & $62 / 17.2$ & $233 / 64.5$ \\
\hline & Male & $267 / 60.8$ & $172 / 39.2$ & $52 / 11.9$ & $34 / 7.7$ & $20 / 4.6$ & $333 / 75.9$ & $95 / 21.6$ & $64 / 14.6$ & $280 / 63.8$ \\
\hline & Total & $496 / 62$ & $304 / 38$ & $74 / 9.3$ & $71 / 8.9$ & $34 / 4.3$ & $621 / 77.6$ & $161 / 20.1$ & $126 / 15.8$ & $513 / 64.1$ \\
\hline \multirow{8}{*}{$\begin{array}{l}\text { Age }(\mathrm{n}= \\
792)\end{array}$} & $18-25$ & $23 / 33.8$ & $45 / 66.2$ & $3 / 4.4$ & $4 / 5.9$ & $1 / 1.5$ & $60 / 88.2$ & $12 / 17.7$ & $5 / 7.4$ & $51 / 75$ \\
\hline & $26-33$ & $59 / 47.6$ & $65 / 52.4$ & $11 / 8.9$ & $4 / 3.2$ & $1 / 0.8$ & $108 / 87.1$ & $20 / 16.1$ & $9 / 7.3$ & $95 / 76.6$ \\
\hline & $34-41$ & $88 / 60.3$ & $58 / 39.7$ & $12 / 8.2$ & $16 / 11$ & $5 / 3.4$ & $113 / 77.4$ & $34 / 23.3$ & $20 / 13.7$ & $92 / 63$ \\
\hline & $42-49$ & $77 / 66.4$ & $39 / 33.6$ & $17 / 14.7$ & $10 / 8.6$ & $5 / 4.3$ & $84 / 72.4$ & $28 / 24.1$ & $19 / 16.4$ & $69 / 59.5$ \\
\hline & $50-57$ & $80 / 69.6$ & $35 / 30.4$ & $16 / 13.9$ & $13 / 11.3$ & $3 / 2.6$ & $83 / 72.2$ & $26 / 22.6$ & $21 / 18.3$ & $68 / 59.1$ \\
\hline & $58-65$ & $80 / 79.2$ & $21 / 20.8$ & $7 / 6.9$ & $7 / 6.9$ & $10 / 9.9$ & $77 / 76.2$ & $18 / 17.8$ & $28 / 27.7$ & $55 / 54.5$ \\
\hline & $>65$ & $84 / 68.9$ & $38 / 31.1$ & $6 / 4.9$ & $17 / 13.9$ & $9 / 7.4$ & $90 / 73.8$ & $20 / 16.4$ & $23 / 18.9$ & $79 / 64.8$ \\
\hline & Total & $491 / 62$ & $301 / 38$ & $72 / 9.1$ & $71 / 9$ & $\begin{array}{l}34 / \\
4.3 \\
\end{array}$ & $615 / 77.7$ & $158 / 20$ & $125 / 15.8$ & $\begin{array}{l}509 / \\
64.27 \\
\end{array}$ \\
\hline \multirow[t]{8}{*}{$\begin{array}{l}\text { Education } \\
(\mathrm{n}=800)\end{array}$} & $\begin{array}{l}\text { No formal } \\
\text { education }\end{array}$ & $205 / 66.3$ & $104 / 33.7$ & $24 / 7.8$ & $36 / 11.7$ & $15 / 4.9$ & $234 / 75.73$ & $49 / 15.9$ & $64 / 20.7$ & $196 / 63.4$ \\
\hline & $1-4$ & $78 / 70.9$ & $32 / 29.1$ & $13 / 11.8$ & $11 / 10$ & $4 / 3.6$ & $82 / 74.6$ & $29 / 26.4$ & $12 / 10.9$ & $69 / 62.7$ \\
\hline & $5-8$ & $104 / 65$ & $56 / 35$ & $16 / 10$ & $12 / 7.5$ & $10 / 6.3$ & $122 / 76.3$ & $37 / 23.1$ & $28 / 17.5$ & $95 / 59.4$ \\
\hline & $9-10$ & $64 / 47.1$ & $72 / 52.9$ & $7 / 5.2$ & $9 / 6.6$ & $3 / 2.2$ & $11 / 86$ & $17 / 12.5$ & $13 / 9.6$ & $106 / 77.9$ \\
\hline & $11-12$ & $18 / 47.4$ & $20 / 52.6$ & $2 / 5.3$ & $2 / 5.3$ & 0 & $34 / 89.4$ & $10 / 26.3$ & $4 / 10.5$ & $24 / 63.1$ \\
\hline & Diploma & $16 / 59.3$ & $11 / 40.7$ & $7 / 25.9$ & $1 / 3.7$ & $2 / 7.4$ & $17 / 63$ & $11 / 40.7$ & $4 / 14.8$ & $12 / 44.4$ \\
\hline & $\begin{array}{c}1^{\text {st }} \text { degree } \\
\& \text { above }\end{array}$ & $11 / 55$ & $9 / 45$ & $5 / 25$ & 0 & 0 & $15 / 75$ & $8 / 40$ & $1 / 5$ & $11 / 55$ \\
\hline & Total & $496 / 62$ & $304 / 38$ & $74 / 9.3$ & $71 / 8.9$ & $34 / 4.3$ & $621 / 77.6$ & $161 / 20.1$ & $126 / 15.8$ & $513 / 64.1$ \\
\hline \multirow{8}{*}{$\begin{array}{l}\text { Occupation } \\
(\mathrm{n}=800)\end{array}$} & Civil servant & $28 / 71.8$ & $11 / 28.2$ & 9/23.1 & $2 / 5.1$ & $6 / 15.4$ & 2256.4 & $15 / 38.5$ & $8 / 20.5$ & $16 / 41$ \\
\hline & Merchant & $72 / 49.7$ & $73 / 50.3$ & $9 / 6.2$ & $14 / 9.7$ & $3 / 2.1$ & $119 / 82.1$ & $29 / 20$ & $17 / 11.7$ & $99 / 68.3$ \\
\hline & Farmer & $288 / 64.1$ & $161 / 35.9$ & $46 / 10.2$ & $34 / 7.6$ & $17 / 3.8$ & $352 / 78.4$ & $78 / 17.4$ & $70 / 15.6$ & $301 / 67$ \\
\hline & $\begin{array}{c}\text { Daily } \\
\text { worker }\end{array}$ & $28 / 63.6$ & $16 / 36.4$ & $3 / 6.8$ & $4 / 9.1$ & $2 / 4.6$ & $35 / 79.6$ & $14 / 31.8$ & $9 / 20.5$ & $21 / 47.7$ \\
\hline & Students & $4 / 30.7$ & $9 / 69.2$ & $1 / 7.7$ & 0 & 0 & $12 / 92.3$ & $1 / 7.7$ & $2 / 15.4$ & $10 / 76.9$ \\
\hline & tOther & $9 / 75$ & $3 / 25$ & $3 / 25$ & $1 / 8.3$ & 0 & $8 / 66.7$ & $6 / 50$ & $1 / 8.3$ & $5 / 41.7$ \\
\hline & Unemployed & $67 / 68.7$ & $31 / 31.6$ & $3 / 3.1$ & $16 / 16.3$ & $6 / 6.1$ & $73 / 4.5$ & $\begin{array}{l}18 / 18.4 \\
\end{array}$ & $19 / 19.4$ & $61 / 62.2$ \\
\hline & Total & $496 / 62$ & $304 / 38$ & $74 / 9.3$ & $71 / 8.9$ & $34 / 4.3$ & $621 / 77.6$ & $161 / 20.1$ & $126 / 15.8$ & $513 / 64.1$ \\
\hline \multirow{4}{*}{$\begin{array}{l}\text { Animal } \\
\text { ownership } \\
(\mathrm{n}=800)\end{array}$} & Have & $298 / 65.9$ & $154 / 34.1$ & $52 / 11.5$ & $42 / 9.3$ & $19 / 4.2$ & $339 / 75$ & $87 / 19.3$ & $82 / 18.1$ & $283 / 62.6$ \\
\hline & Have not & $198 / 56.9$ & $150 / 43.1$ & $22 / 6.3$ & $29 / 8.3$ & $15 / 4.3$ & $282 / 81$ & \begin{tabular}{|l|}
$74 / 21.3$ \\
\end{tabular} & $\begin{array}{l}44 \\
(12.6) \\
\end{array}$ & $230 / 66.1$ \\
\hline & Total & $496 / 62$ & $304 / 38$ & $74 / 9.3$ & $71 / 8.9$ & $34 / 4.3$ & $621 / 77.6$ & $161 / 20.1$ & $126 / 15.8$ & $513 / 64.1$ \\
\hline & Total & $496 / 62$ & $304 / 38$ & $74 / 9.3$ & $71 / 8.9$ & $34 / 4.3$ & $621 / 77.6$ & $161 / 20.1$ & $126 / 15.8$ & $513 / 64.1$ \\
\hline \multirow[t]{4}{*}{$\begin{array}{l}\text { District } \\
(\mathrm{n}=800)\end{array}$} & Adigrat & $152 / 64.1$ & $85 / 35.9$ & $20 / 8.4$ & $\begin{array}{l}24 / \\
10.1 \\
\end{array}$ & $15 / 6.3$ & $178 / 75.1$ & $69 / 29.1$ & $53 / 22.4$ & $115 / 48.5$ \\
\hline & Gulomkada & $155 / 50$ & $155 / 50$ & $44 / 14.2$ & $8 / 2.6$ & $9 / 2.9$ & $249 / 80.3$ & $53 / 17.1$ & $20 / 6.5$ & $237 / 76.5$ \\
\hline & $\begin{array}{l}\text { Ganta- } \\
\text { afeshum }\end{array}$ & $189 / 74.7$ & $64 / 25.3$ & $10 / 4$ & $39 / 15.4$ & $10 / 4$ & $194 / 76.7$ & $39 / 15.4$ & $53 / 21$ & $161 / 63.6$ \\
\hline & Total & $496 / 62$ & $304 / 38$ & $74 / 9.3$ & $71 / 8.9$ & $34 / 4.3$ & $621 / 77.6$ & $161 / 20.1$ & $126 / 15.8$ & $513 / 64.1$ \\
\hline
\end{tabular}

* Heredity, witchcraft, lack of sanitation, hunger, insects, thirst

†Private company worker, retired

Table 3: Knowledge on the disease, its cause and zoonotic nature by the professional respondents 


\begin{tabular}{|c|c|c|c|c|c|c|c|c|c|c|}
\hline \multicolumn{2}{|l|}{ Variable } & \multicolumn{3}{|c|}{$\begin{array}{l}\text { Knowledge on the cause of the } \\
\text { disease }\end{array}$} & \multicolumn{3}{|c|}{ Forms of the disease $\dagger$} & \multicolumn{3}{|c|}{ Zoonotic nature } \\
\hline & & $\begin{array}{l}\text { Bacteria } \\
(\mathrm{n} / \%)\end{array}$ & $\begin{array}{l}* \text { Other } \\
(\mathrm{n} / \%)\end{array}$ & $\begin{array}{l}\text { Don't } \\
\text { know } \\
(\mathrm{n} / \%)\end{array}$ & $\begin{array}{l}\text { Cutaneous } \\
(\mathrm{n} / \%)\end{array}$ & $\begin{array}{l}\text { GIT } \\
(\mathrm{n} / \%)\end{array}$ & $\begin{array}{l}\text { Respiratory } \\
(\mathrm{n} / \%)\end{array}$ & $\begin{array}{l}\text { Yes } \\
(\mathrm{n} / \%)\end{array}$ & $\begin{array}{l}\text { No } \\
\text { (n/\%) }\end{array}$ & $\begin{array}{l}\text { Don't } \\
\text { know } \\
(\mathrm{n} / \%)\end{array}$ \\
\hline \multirow[t]{3}{*}{ Sex $(n=61)$} & Female & $9 / 30$ & $5 / 16.7$ & $16 / 53.3$ & $23 / 76.7$ & $11 / 36.7$ & $11 / 36.7$ & $26 / 86.7$ & $2 / 6.7$ & $2 / 6.7$ \\
\hline & Male & $25 / 80.6$ & $1 / 3.2$ & $5 / 16.1$ & $18 / 58.1$ & $10 / 32.3$ & $11 / 35.5$ & $29 / 93.6$ & $2 / 6.5$ & 0 \\
\hline & Total & $34 / 55.7$ & $6 / 9.8$ & $21 / 34.4$ & $41 / 67.2$ & $21 / 34.4$ & $22 / 36.1$ & $55 / 90.1$ & $4 / 6.6$ & $2 / 3.3$ \\
\hline \multirow[t]{6}{*}{ Age $(n=43)$} & 18-25 & $6 / 80$ & 0 & $4 / 40$ & $7 / 70$ & $4 / 40$ & $3 / 30$ & $7 / 70$ & $2 / 20$ & $1 / 10$ \\
\hline & $26-33$ & $15 / 68.2$ & $2 / 9.1$ & $5 / 22.7$ & $16 / 72.7$ & $8 / 36.1$ & $11 / 50$ & $\begin{array}{l}20 / \\
90.9 \\
\end{array}$ & $1 / 4.6$ & $1 / 4.6$ \\
\hline & $34-41$ & $1 / 20$ & $1 / 20$ & $3 / 33.3$ & $4 / 80$ & $1 / 20$ & $1 / 20$ & $5 / 100$ & 0 & 0 \\
\hline & $42-49$ & $1 / 33.3$ & $1 / 33.3$ & $1 / 33.3$ & $1 / 33.3$ & $2 / 66.7$ & $1 / 33.3$ & $3 / 100$ & 0 & 0 \\
\hline & $>49$ & $2 / 66.7$ & $1 / 33.3$ & 0 & $2 / 66.7$ & 0 & $1 / 33.3$ & $3 / 100$ & 0 & 0 \\
\hline & Total & $25 / 58.1$ & $5 / 11.6$ & $13 / 30.2$ & $30 / 69.8$ & $\begin{array}{l}15 / \\
34.9 \\
\end{array}$ & $17 / 39.5$ & $38 / 88.4$ & $3 / 7$ & $2 / 4.7$ \\
\hline \multirow{4}{*}{$\begin{array}{l}\text { Education } \\
(\mathrm{n}=60)\end{array}$} & Diploma & $19 / 51.4$ & $4 / 10.8$ & $14 / 37.8$ & $24 / 64.7$ & $9 / 24.3$ & $12 / 32.4$ & $35 / 94.6$ & $1 / 2.7$ & $1 / 2.7$ \\
\hline & Degree & $12 / 60$ & $2 / 10$ & $6 / 30$ & $15 / 75$ & $9 / 45$ & $8 / 40$ & $16 / 80$ & $3 / 15$ & $1 / 5$ \\
\hline & MSc & $3 / 100$ & 0 & 0 & $2 / 66.7$ & $3 / 100$ & $2 / 66.7$ & $3 / 100$ & 0 & 0 \\
\hline & Total & $34 / 56.7$ & $6 / 10$ & $20 / 33.3$ & $41 / 68.3$ & $21 / 35$ & $22 / 36.7$ & $54 / 90$ & $4 / 6.7$ & $2 / 3.3$ \\
\hline \multirow{4}{*}{$\begin{array}{l}\text { District } \\
(\mathrm{n}=62)\end{array}$} & Adigrat & $8 / 32$ & $5 / 20$ & $12 / 48$ & $18 / 72$ & $6 / 24$ & $6 / 24$ & $19 / 76$ & $4 / 16$ & $2 / 8$ \\
\hline & Gulomkada & $15 / 88.2$ & 0 & $2 / 17.8$ & $10 / 58.8$ & $10 / 58.8$ & $8 / 47.1$ & $17 / 100$ & 0 & 0 \\
\hline & $\begin{array}{l}\text { Ganta- } \\
\text { afeshum }\end{array}$ & $12 / 60$ & $1 / 5$ & $7 / 35$ & $14 / 70$ & $5 / 25$ & $8 / 40$ & $20 / 100$ & 0 & 0 \\
\hline & Total & $35 / 56.5$ & $6 / 9.7$ & $21 / 33.9$ & $42 / 67.7$ & $21 / 33.9$ & $22 / 35.5$ & $56 / 90.3$ & $4 / 6.5$ & $2 / 3.2$ \\
\hline \multirow{3}{*}{$\begin{array}{l}\text { Profession } \\
(\mathrm{n}=62)\end{array}$} & HHPs & $22 / 44.9$ & $6 / 12$ & $21 / 42.9$ & $34 / 69.4$ & $17 / 34.7$ & $16 / 32.6$ & $43 / 87.8$ & $4 / 8.1$ & $2 / 4.1$ \\
\hline & AHEs & $13 / 100$ & 0 & 0 & $8 / 61.5$ & $4 / 30.8$ & $6 / 46.1$ & $13 / 100$ & 0 & 0 \\
\hline & Total & $35 / 56.5$ & $6 / 9.7$ & $21 / 33.9$ & $42 / 67.7$ & $21 / 33.9$ & $22 / 35.5$ & $56 / 90.3$ & $4 / 6.5$ & $2 / 3.2$ \\
\hline
\end{tabular}

tthere were individuals who knew more than two form of the disease

* Leishmania, fly

Table 4: knowledge of the community members and professional respondents towards anthrax symptoms, transmission routes and control/prevention methods in animals 


\begin{tabular}{|c|c|c|c|c|}
\hline & \multicolumn{2}{|c|}{ Professionals } & \multicolumn{2}{|c|}{ Community } \\
\hline Variable & $\begin{array}{l}\text { Frequency }(\mathrm{n}= \\
62) \\
\end{array}$ & $\%$ & $\begin{array}{l}\text { Frequency }(\mathrm{n}= \\
800)\end{array}$ & $\%$ \\
\hline Number who did not knew anthrax symptoms (n/\%) & 16 & 25.8 & 590 & 73.8 \\
\hline Number who knew anthrax symptoms (n/\%) & 46 & 74.2 & 210 & 26.3 \\
\hline Sudden death & 33 & 53.2 & 115 & 14.4 \\
\hline Un-clotted dark red blood & 26 & 41.9 & 32 & 3 \\
\hline Bleeding from natural orifices & 29 & 46.8 & 24 & 4 \\
\hline Incomplete rigor mortis & 17 & 27.4 & 14 & 1.8 \\
\hline Other (swelling, wound, pain, fatigue, etc) & 8* & $12.9 *$ & 78 & 9.8 \\
\hline Number who did not knew anthrax transmission (n/\%) & 13 & 21 & 630 & 78.8 \\
\hline Number who knew anthrax transmission $(\mathrm{n} / \%)$ & 49 & 79 & 170 & 21.3 \\
\hline Ingesting of blood contaminated grass & 33 & 53.2 & 104 & 13 \\
\hline Drinking contaminated water & 30 & 48.4 & 76 & 9.5 \\
\hline Licking anthrax dead bones & 24 & 38.7 & 33 & 4.1 \\
\hline Through contaminated soil & 35 & 56.5 & 67 & 8.4 \\
\hline Believe its transmission but did not tell the method & 7 & 11.3 & & \\
\hline Other (inhalation, contact) & - & - & 7 & 0.9 \\
\hline $\begin{array}{l}\text { Number who did not knew anthrax control/prevention methods } \\
(\mathrm{n} / \%)\end{array}$ & 13 & 21 & 453 & 56.6 \\
\hline Number who knew anthrax control/prevention methods (n/\%) & 49 & 79 & 347 & 43.4 \\
\hline Isolate/separate anthrax infected animals & 33 & 53.2 & 61 & 7.6 \\
\hline Avoid with anthrax infected people & - & - & 37 & 4.6 \\
\hline Burn all suspected anthrax animal carcasses & 27 & 43.6 & 33 & 4.1 \\
\hline Bury all suspected anthrax carcasses & 32 & 51.6 & 22 & 2.8 \\
\hline Vaccinate animals & 42 & 67.7 & 1 & 0.1 \\
\hline Bury and burn all suspected anthrax carcasses & 22 & 35.5 & 1 & 0.1 \\
\hline Using Traditional medicine & - & & 36 & 4.5 \\
\hline
\end{tabular}

*swelling, black wound, diarrhoea, bloat

Table 5: knowledge of the community member and professional respondents towards anthrax symptoms, transmission routes and control/prevention methods in humans 


\begin{tabular}{|c|c|c|c|c|}
\hline & \multicolumn{2}{|c|}{ Professionals } & \multicolumn{2}{|c|}{ Community } \\
\hline Variable & $\begin{array}{l}\text { Frequency } \\
(\mathrm{n}=62)\end{array}$ & $\%$ & $\begin{array}{l}\text { Frequency } \\
(\mathrm{n}=800)\end{array}$ & $\%$ \\
\hline Number who did not knew anthrax symptoms (n/\%) & 6 & 9.7 & 506 & 63.3 \\
\hline Number who knew anthrax symptoms (n/\%) & 56 & 90.3 & 294 & 36.8 \\
\hline Fever & 39 & 62.9 & 181 & 22.4 \\
\hline Chills & 28 & 45.1 & 80 & 10 \\
\hline Fatigue & 31 & 50 & 37 & 4.6 \\
\hline Skin rash/wounds & 41 & 66.1 & 68 & 8.5 \\
\hline Coughing & 22 & 35.5 & 16 & 2 \\
\hline Lack of appetite & 29 & 45.2 & 25 & 3.1 \\
\hline Headache & 25 & 40.3 & 15 & 1.9 \\
\hline Irritability & 15 & 24.1 & 10 & 1.3 \\
\hline Diarrhea & 17 & 27.4 & 7 & 0.8 \\
\hline Vomiting & 21 & 33.9 & 8 & 1 \\
\hline Sweating & 21 & 33.9 & 12 & 1.5 \\
\hline Other (swelling, wound, pain, itching, etc) & $1^{*}$ & $1.6^{*}$ & 102 & 12.8 \\
\hline Number who did not knew anthrax transmission (n/\%) & 6 & 9.7 & 639 & 79.9 \\
\hline Number who knew anthrax transmission (n/\%) & 56 & 90.3 & 161 & 20.1 \\
\hline Eating infected animal product (raw meat \& milk) & 52 & 83.9 & 127 & 15.9 \\
\hline $\begin{array}{l}\text { Handling infected animals and animal products without protective } \\
\text { clothing }\end{array}$ & 28 & 45.1 & 66 & 8.3 \\
\hline Through contaminated soil & 24 & 38.7 & 28 & 3.5 \\
\hline Number who did not knew anthrax control/prevention methods (n/\%) & 5 & 8.1 & 435 & 54.4 \\
\hline Number who knew anthrax control/prevention methods (n/\%) & 57 & 91.9 & 365 & 45.6 \\
\hline Avoid contact with anthrax infected animals & 32 & 51.6 & 59 & 7.4 \\
\hline Avoid contact with anthrax infected people & 22 & 35.5 & 35 & 4.4 \\
\hline By avoiding eating anthrax infected animal products & 44 & 71 & 63 & 7.9 \\
\hline Bury all suspected anthrax carcasses & 34 & 54.8 & 28 & 3.5 \\
\hline Burn all suspected anthrax animal carcasses & 28 & 45.1 & 20 & 2.5 \\
\hline Bury and burn all suspected anthrax carcasses & 22 & 35.5 & 7 & 0.9 \\
\hline Vaccinate animals & 42 & 67.7 & 276 & 34.5 \\
\hline Using traditional medicine & - & - & 10 & 1.3 \\
\hline Other (Keeping good hygiene/sanitation and nutrition) & - & - & 9 & 1.1 \\
\hline
\end{tabular}

*itching

Table 6: Attitude and practice of community member respondents 


\begin{tabular}{|c|c|c|c|}
\hline Question & Response & Frequency & $\%$ \\
\hline \multirow[t]{4}{*}{ What animal husbandry do you practice? $(\mathrm{n}=452)$} & Free grazing & 84 & 19 \\
\hline & Zero grazing & 354 & 80.1 \\
\hline & Mixed (free and zero) & 4 & 0.9 \\
\hline & No report & 10 & 2 \\
\hline \multirow{3}{*}{$\begin{array}{l}\text { Have you ever had anthrax infected animal(s)? }(\mathrm{n}= \\
\text { 800) }\end{array}$} & Yes & 32 & 4 \\
\hline & No & 392 & 49 \\
\hline & Do not know & 376 & 47 \\
\hline \multirow[t]{6}{*}{ If yes, what action did you take? $(n=32)$} & Reported to the Veterinarian & 8 & 25 \\
\hline & If died, buried the dead animal & 5 & 15.6 \\
\hline & Consumed meat of the dead animal & 0 & 0 \\
\hline & Remove away the dead animal & 7 & 21.9 \\
\hline & $\begin{array}{l}\text { Use Traditional medication (local medicine, } \\
\text { bleeding and branded) }\end{array}$ & 9 & 28.1 \\
\hline & No report & 3 & 9.4 \\
\hline \multirow{3}{*}{$\begin{array}{l}\text { Has any member of your family infected with } \\
\text { anthrax? }(\mathrm{n}=800)\end{array}$} & Yes & 84 & 10.5 \\
\hline & No & 404 & 50.5 \\
\hline & Do not know & 312 & 39 \\
\hline \multirow[t]{7}{*}{ If yes, what action did you take? $(\mathrm{n}=84)$} & Took the person to health facility & 3 & 3.6 \\
\hline & bought drug from pharmacy & 0 & 0 \\
\hline & Took to a local healer & 60 & 71.4 \\
\hline & We did nothing & 2 & 2.4 \\
\hline & $\begin{array}{l}\text { use both (took to health center and local } \\
\text { healer) }\end{array}$ & 2 & 2.4 \\
\hline & Do not know & 1 & 1.2 \\
\hline & No report & 16 & 19.1 \\
\hline \multirow{3}{*}{$\begin{array}{l}\text { Do you think that vaccination of animals can prevent } \\
\text { anthrax in animals? }(n=800)\end{array}$} & Yes & 416 & 52 \\
\hline & No & 44 & 5.5 \\
\hline & Do not know & 340 & 42.5 \\
\hline \multirow{3}{*}{$\begin{array}{l}\text { Do you think that vaccination of animals can prevent } \\
\text { anthrax in humans? }(n=800)\end{array}$} & Yes & 259 & 32.4 \\
\hline & No & 134 & 16.8 \\
\hline & Do not know & 407 & 50.9 \\
\hline \multirow{3}{*}{$\begin{array}{l}\text { Do you think that anthrax is a serious disease of } \\
\text { animals? }(n=800)\end{array}$} & Yes & 78 & 9.8 \\
\hline & No & 418 & 52.3 \\
\hline & Do not know & 304 & 38 \\
\hline \multirow{3}{*}{$\begin{array}{l}\text { Do you think that anthrax is a serious disease of } \\
\text { humans? }(n=800)\end{array}$} & Yes & 90 & 11.3 \\
\hline & No & 406 & 50.8 \\
\hline & Do not know & 304 & 38 \\
\hline \multirow{3}{*}{$\begin{array}{l}\text { Were your animals vaccinated against anthrax? }(\mathrm{n}= \\
\text { 800) }\end{array}$} & Yes & 35 & 4.4 \\
\hline & No & 28 & 3.5 \\
\hline & Do not know & 737 & 92.1 \\
\hline
\end{tabular}

\section{Figures}



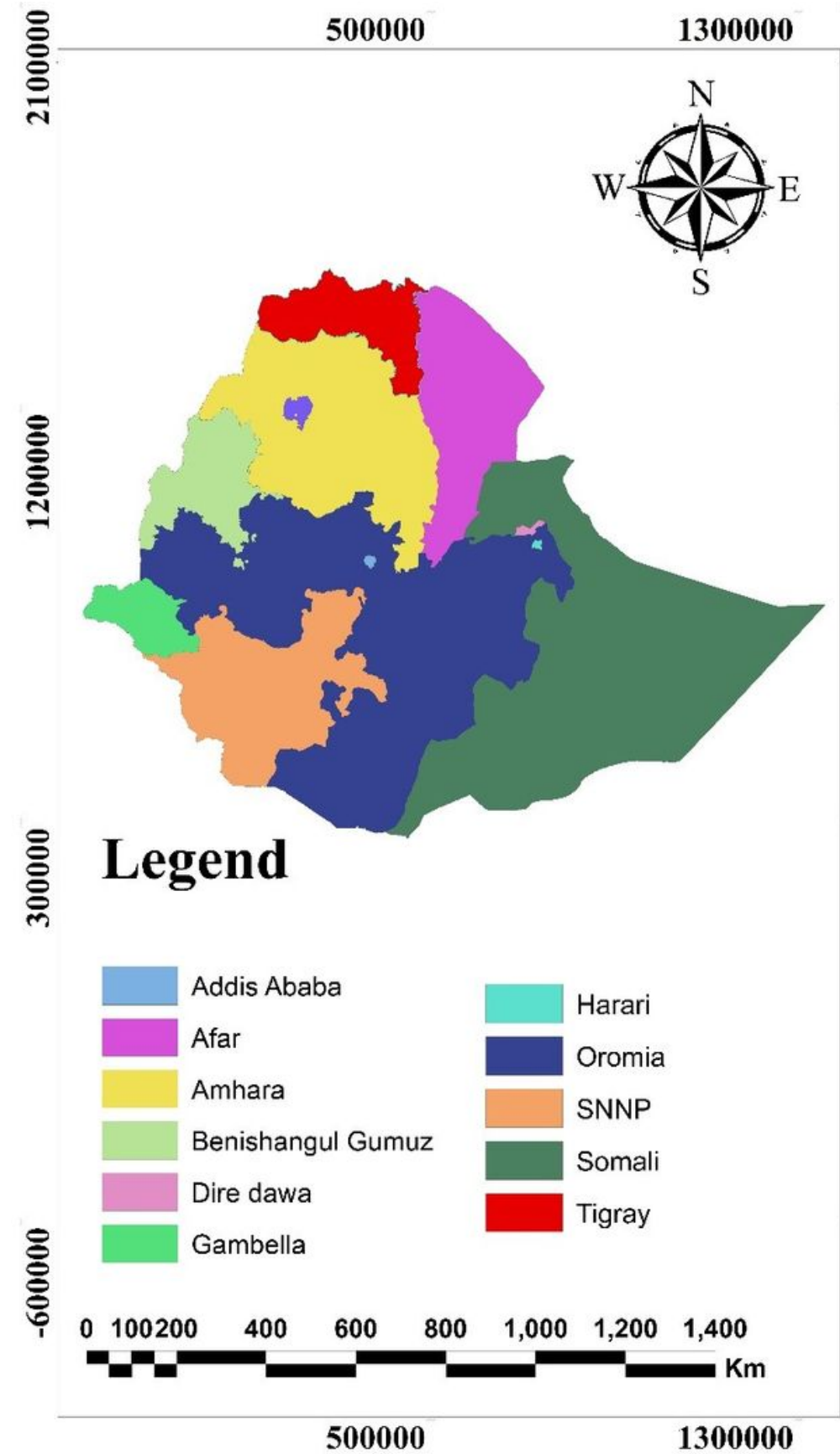
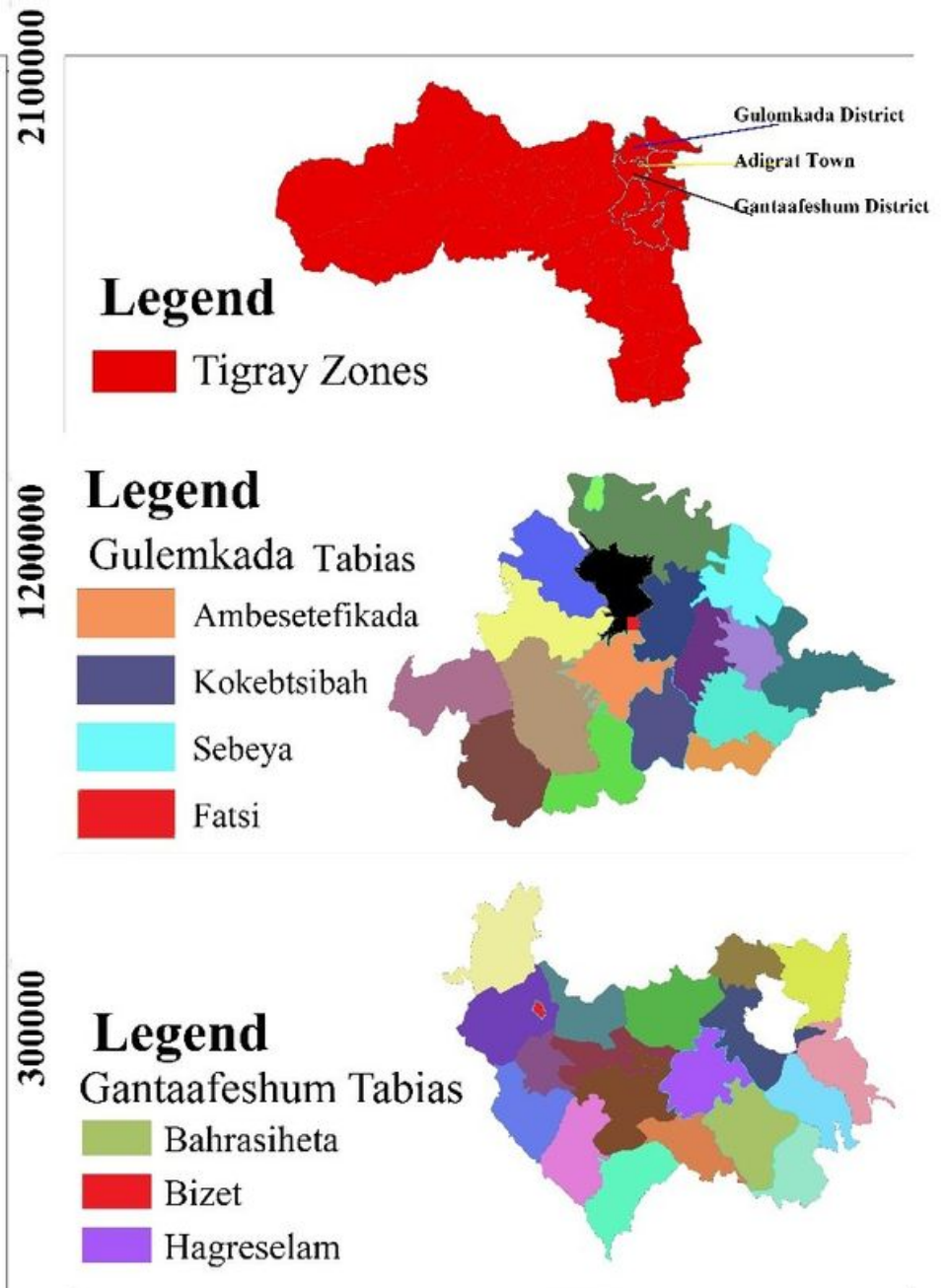

\section{Legend}

Adigrat Tabias

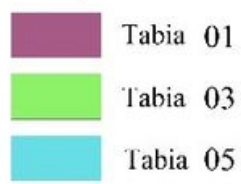

Figure 1

Map of the study area

\section{Supplementary Files}

This is a list of supplementary files associated with this preprint. Click to download.

- Additionalfile.docx 